\title{
GAMIFIKÁCIÓ A PEDAGÓGIÁBAN
}

\section{Szerzők:}

\author{
Jaskóné Gácsi Mária (PhD) \\ Miskolci Egyetem
}

Szerző e-mail címe:

maria.gjasi@gmail.com

\section{Lektorok:}

Szabóné Balogh Ágota (PhD)

Gál Ferenc Főiskola

Stóka György (PhD)

Eszterházy Károly Egyetem

...és további két anonim lektor

\section{Absztrakt}

A gamifikáció az utóbbi években vált az oktatás és az oktatáskutatás egyik kiemelt területévé. A tanítási folyamat során két részegység is gamifikálható. Az egyik az óra menetét érintő, azaz tartalmi gamifikáció. A tanítási folyamat másik gamifikálható részegysége a számonkérésértékelés, ez a strukturális gamifikáció. A gamifikáció hatása, bár alapvetően pozitívnak tűnik, mégsem egyértelmű. Ennek egyik oka, hogy a kutatások során nem minden esetben azonos módon használnak bizonyos fogalmakat, továbbá nem tisztáznak minden tanulásszervezési körülményt. Jelen tanulmány célja annak bemutatása, hogy a tervezés és alkalmazás során mire kell figyelmet fordítani, továbbá, hogy melyek a mérhető hatások, és milyen esetekben találták azt a kutatók, hogy a gamifikáció nem járt valójában mérhető, megfogható hatással.

Kulcsszavak: gamifikáció, játékos tervezés, játék alapú tanulás

Diszciplinák: pszichológia, pedagógia, informatika

\section{Abstract \\ GAMIFICATION IN PED AGOGY}

Gamification has become one of the priority areas of education and research in recent years. Two components can be gamified during the teaching process. One is the gamification of the lesson, ie content gamification. Another gamifiable component of the teaching process is accountability assessment, this is structural gamification. The effect of gamification, though fundamentally positive, is not clear. One reason for this is that research does not always use the same concepts in the same way, nor does it clarify every learning organization. The 
purpose of this study is to illustrate what needs to be considered in design and implementation, and what the measurable effects are, and in what cases researchers have found that gamification did not actually have a measurable, tangible effect.

Keywords: gamification, player design, game based learning

Disciplines: psychology, pedagogy, informatics

Jaskóné Gácsi Mária (2020): Gamifikáció a pedagógiában. Mesterséges intelligencia - interdiszciplináris folyóirat, II. évf. 2020/1. szám. 83-91. doi: 10.35406/MI.2020.1.83

A gamifikáció az utóbbi években vált az oktatás és az oktatáskutatás egyik kiemelt területévé. Bár egyre több tanulmány születik a témában, a fogalmak használta még nem egyértelmû, ami akár a hatás mérését, a gamifikáció értékelését is befolyásolhatja. Az is látható, hogy az egyes európai országok eltérő szakaszban járnak az oktatás és a játékosítás kapcsolatának feltérképezését és a gamifikált oktatás alkalmazását illetően. A következőkben áttekintjük a témához kapcsolódó fogalmakat, és kísérletet teszünk ezek tisztázására. Bemutatjuk azt is, hogy a tervezés és alkalmazás során mire kell figyelmet fordítani, továbbá, hogy melyek a mérhetô hatások, és milyen esetekben találták azt a kutatók, hogy a gamifikáció nem járt valójában mérhető, megfogható hatással.

A gamifikáció fogalma már 2002-ben megjelent, ekkor még az elektronikus eszközök kapcsán. Elterjedni 2010-ben kezdett, továbbra is a digitális médiához fűződően, majd a következő két év során összekapcsolódott az oktatás témájával is. Az oktatás terén tapasztalható nagy érdeklődést elsősorban an- nak tulajdonítják, hogy a gamifikáció egy újfajta motivációs lehetőség, ami a többi módszerrel összevetve jobban alkalmazkodik a Z generáció igényeihez (Balogh 2017, Borges és tsai, 2014, Kovácsné 2018).

A gamifikáció legegyszerūbb definíciói csupán annyit tartalmaznak, hogy ez játékelemek és játéktervezési elemek használata nem-játékos kontextusban. A valamivel bővebb definíció már hozzáteszi, hogy ezek célja a motiváció és az elkötelezettség növelése. Az esetek egy részében viszont olyan tanulási folyamatokat is gamifikációnak neveznek, amely során egy-egy játék tanulási célra adaptált változatát használják, azonban ez a játékalapú tanulás (Game-Based Learning, GBL) körébe tartozik (Borges et al. 2014, Caponetto és tsai, 2014).

\section{A gamifikáció meghatározása, a fogalmak tisztázása}

Annak érdekében, hogy a gamifikációt biztonsággal azonosíthassuk, érdemes áttekinteni a kapcsolódó fogalmakat. 
Játékjellegü dirájn (playful design): olyan esztétikai elemek vagy játékokból kiemelt összetevők használata nem-játékos környezetben, amelyek célja, hogy megragadják a felhasználó figyelmét, gyakran érzelmi választ is kiváltanak. Ilyen kép megjelenhet akár egy mobilapplikáció „várakozó” oldalán is, az ilyenkor használt „türelmet kérünk”, vagy „azonnal” kifejezések helyett. A cél ilyenkor az, hogy az érzelmi válasz megszüntesse vagy csökkentse a várakozás miatt fellépő bosszúságot.

Komoly játékok (serious games): olyan játékok, amelyeket nem a kikapcsolódás kontextusában, oktatási céllal hoztak létre. A „komoly” jelzőt azért kapták, mert olyan témákkal foglalkoznak, amilyen például a közgazdaságtan, az egészségügy, az ipar, az oktatás vagy a politika. Az ilyen játékok célja lehet valós helyzeteket szimulálni, a valódi szituáció kockázatvállalása nélkül. A „Virtual Incident Management Training System" például mentősök és rendőrök számára készült oktatóprogram, amely azt gyakoroltatja, mit kell tenni, ha autópályákon történik baleset.

Videojátékok vagy digitális játékok: ezek olyan játékok, amelyek során a felhasználó elképzelt kihívásokkal néz szembe és problémákat old meg. Interaktívak és folyamatos visszacsatolást nyújtanak a felhasználónak, ami érzelmi reakciót is kivált. Az ilyen játékok egyik ikonikus alakja például Super Mario.

Gamifikáció: játékok során kifejlesztett technikák használata nem-játékos környezetben. Ezek a technikák képesek motiválni a felhasználót és fenntartani az érdeklődését, továbbá a problémák megoldására sarkallják. A nem-játékos környezetben ezek az elemek nem központi összetevői a rendszernek, azonban a felhasználót a rendszer használatára buzdítják.

Game-Based Learning (GBL): a gamifikációval gyakran keveredô fogalom. A GBL során olyan szoftert használnak, amely eredetileg játéknak készült, majd oktatási célra adaptálták. Ilyen például a Minecraft játékból készült Minecraft Edu. A gamifikáció és a GBL éles elhatárolását megnehezíti, hogy a GBL alkalmazása során is lehet további játékelemeket használni a tanulási folyamat során (Borges és tsai, 2014, Dicheva és tsai, 2015, Fromann és Damsa 2016, Wiggins 2016).

Ezek a definíciók azért is lényegesek, mert a témával foglalkozó tanulmányok egy része amellett érvel, hogy az oktatás és a játékok kapcsolata nem új keletú. A hatásmechanizmus a hagyományos játékok és a digitális játékok esetében is hasonló pszichés és fejlődésbeli mechanizmusokon alapul. Balogh (2017) például arra hívja fel a figyelmet, hogy a játék nagyon fontos szerepet játszik a nyelvi szocializáció során, és ez a szerep az online játékok esetében is adott: a szerepjátékjellegú játékok sok játékost mozgatnak meg, és közösségi térként is funkcionálnak. Wiggins (2016) kutatása során a gamifikáció, illetve a nem digitális játékok felsőoktatási alkalmazását is összevetette. Utóbbiak közé sorolta a kártyajátékokat, táblás játékokat és a (nem digitális) szimulációs játékokat. Azt tapasztalta, hogy mindössze a megkérdezett oktatók 27 százaléka használ a kurzusain digitális játékokat, miközben nem digitális játékokat 57 százalékuk. Mindössze 17 százalék 
volt azok aránya, akik semmilyen játékkal nem színesítik a tanítási-tanulási folyamatot.

Kérdéses ugyanakkor, hogy a Wiggins által vizsgált nem digitális játékok vagy a más szerzők által felsorolt hagyományos játékok mennyiben feleltethetôk meg a gamifikációnak, érdemes-e egyáltalán párhuzamba állítani a két típust. Hiszen ezek a nem digitális játékok gyakran csak kivételes alkalmakkor vagy epizodikusan jelennek meg, miközben a gamifikáció egyik fontos jellegzetessége a folyamatosság (Balogh 2017, Deterding 2014, Kovácsné 2018, Wiggins 2016).

\section{Az oktatás gamifikálása}

A tanítási folyamat során két részegység is gamifikálható. Az egyik az óra menetét érintő, azaz tartalmi gamifikáció. Ehhez egyre több szoftver áll rendelkezésre. Ilyenek például az edutainment kategóriába tartozó Classcraft és MinecraftEdu, vagy a magyar fejlesztésû Okos Doboz. Utóbbi alsó tagozatra, felső tagozatra és középiskolára bontva kínál feladatokat, több tantárgyból. A gyakorló feladatok osztály, tantárgy és témakör szerint kereshetők. A magyar irodalom gyakorló feladatokat megvizsgálva azt láthatjuk, hogy alapvetően digitalizált teszteket találunk az oldalon. Figyelemre méltó kutatási téma lenne annak vizsgálata, hogy a $Z$ generációhoz tartozó diákok hogyan értékelik ezeket: a feladatok megjelenítése ugyanis nem tartalmaz playful design elemeket, és a szerkezetük sem tér el egy papíralapú teszt szerkezetétől. Általában nem tartalmazzák a gamifikáció más fontos elmeit sem, így például a gyarapodás vizualizációja sem történik meg a használat során, és nem kapunk például többletpontot, ha javítjuk a hibás választ (Balogh 2017, Borges és tsai, 2014, Caponetto és tsai, 2014, Fromann és Damsa 2016).

Szintén magyar nyelvű online felület a Redmenta. Ez alapvetően feladatlapkészítő alkalmazás, amely a pedagógusok munkáját megkönnyítheti, azonban, ahogy ezt az 1. ábrán láthatjuk, a playful design egyáltalán nem jellemzi, még annyira sem, mint az Okos Dobozt.

1. ábra: Egy tešt a Redmenta oldalán. Forrás: redmenta.com

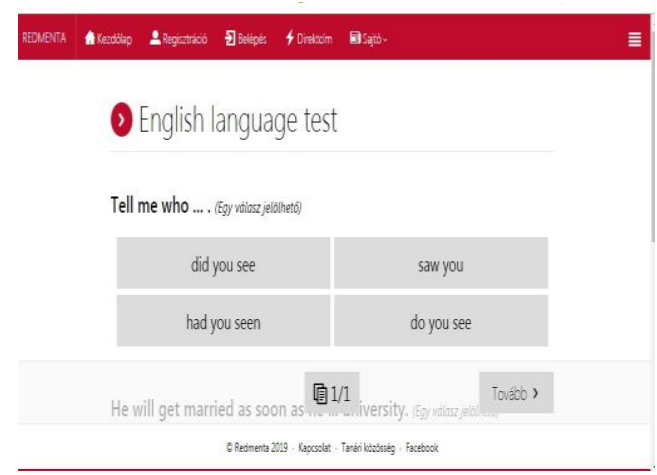

A Classtools angol nyelvű, pedagógusok számára létrehozott oldal. Sokféle feladattípust-játéktípust találunk rajta, például híres személyek számára létrehozható Facebookprofilt, arcade-típusú játékokat, puzzle-t, amiket a tanárok tölthetnek meg tartalommal. A megjelenítés itt már valóban megfelel a playful design elvárásainak, és a felület igyekszik 
mindenre gamifikált megoldást kínálni: még a felelôt is kiválaszthatjuk szerencsekerék segitségével, ahogy azt a 2. ábrán bemutatjuk.

\section{2. ábra: A felelö kiválasztására szolgáló Spinning} Wheel. Forrás: classtools.net

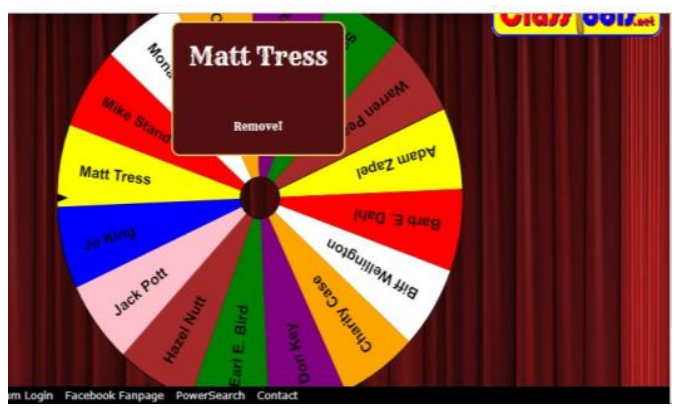

A tanítási folyamat másik gamifikálható részegysége a számonkérés-értékelés, ez a strukturális gamifikáció. Ennek kialakítása során sok tényezőt kell figyelembe venni. A játék egésze során fontos az optimális terhelés, azaz, hogy a feladatok ne legyenek se túlságosan könnyúek, se túl nehezek. Az előbbi esetben unalmassá, utóbbiban frusztrálóvá válik a megoldás. A folyamat egésze során természetesen be lehet iktatni egy könnyű sikerélményt adó egyszerú feladatot, vagy egy komolyabb kihívást jelentő nehezet, összességében azonban úgy kell strukturálni, hogy az optimális szinten maradjon a nehézségi fok. A másik lényeges tényezô az ideális szintezés. A játék végső célja csupán hosszabb idő alatt érhető el, ugyanakkor fontos a megfelelő részcélok kialakítása, mivel ezek segítenek a motiváció fenntartásában. A részcélok elérése valamilyen jutalommal is jár. A jutalmazási rendszer egésze egyébként a harmadik fontos tényező: a teljesítményt követő visszacsatolás az azonnali jutalom, amelynek arányban kell állnia magával a teljesítménnyel. A negyedik lényeges tényező a döntések és választások felkínálása. Ha a diáknak egy-egy ponton lehetősége nyílik valamilyen döntéssel alakítani az eseményeket, az jobban képes a motiváció fenntartására (Fromann és Damsa 2016, Kenéz 2016, Kovácsné 2018).

A gamifikált értékelés során pontszerzés történik, emellett szinteket is célszerú felállítani. A pontszerzés és a szintezés adja a folyamatos előrehaladás érzését, ami a gamifikáció lényeges összetevője (3. ábra). A gamifikált tanulás a kíváncsiság és a csalódásra adott reakció szempontjából különbözik a hagyományos tanulástól: a diák azt érzékeli, hogy valamit teljesített, azaz nem kudarcot él meg. Ha pedig még jobb eredményt szeretne elérni, az a tanulási hibák javítására ösztönzi. Gamifikációs elem a verseny, továbbá a csapatmunka, ami egyéni teljesítésekkel váltakozva jelenik meg (Fromann és Damsa 2016, Kovácsné 2018, Turan és tsai, 2016).

3. ábra: Visszajelzớ képernyô egy gamifikációs kísérlet során. Forrás: Turan és tsai., 2016.

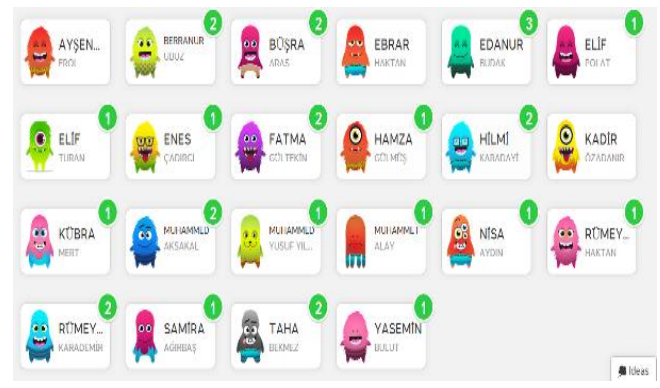




\section{A gamifikáció hatásai, kutatások a témában}

A gamifikáció hatása, bár alapvetôen pozitívnak tűnik, mégsem egyértelmű. Ennek egyik oka, hogy a kutatások során nem minden esetben azonos módon használnak bizonyos fogalmakat, továbbá nem tisztáznak minden tanulásszervezési körülményt. A tervezés során például csak nagyon kevés esetben figyelnek a memória múködésének sajátosságaira.

Clark és munkatársai (2006) épp ezt vizsgálták, és arra jutottak, hogy a gamifikáció pozitív hatásának elmaradása összefügghet a munkamemória és a tartós memória sajátosságaival, a memória kapacitásával. Azaz a gamifikált tanulást úgy kellene megszervezni, hogy a figyelem ne legyen túlságosan széttartó és a redundancia ne lépjen át bizonyos szinteket.

További akadály a hatás egyértelmű mérése szempontjából, hogy a gamifikációval foglalkozó tanulmányok közel kétharmada elméleti, csupán 30-40 százalékuk vizsgál valamilyen konkrét folyamatot. Utóbbiak esetében pedig gondot jelent egyebek mellett, hogy a gamifikáció fogalmát gyakran olyan tanulási folyamatra használják, amikor valamilyen játék adaptációja készül el tanulási céllal, noha ez a Game-Based Learning körébe tartozik (Caponetto és tsai., 2014, Dicheva és tsai., 2015, Majuri és tsai., 2018).

Utóbbit vizsgálva Carlo és munkatársai (2013) a Game-Based Learninggel foglalkozó tanulmányok áttekintése során azt figyelték meg, hogy bár a szakirodalom arról számol be, hogy a diákok többsége a GBL alkalmazását pozitívnak értékelte, az nem derült ki, hogy pontosan miben is nyilvánul meg ez a jó hatás.

Domingez és munkatársai (2013) a gamifikáció hatását vizsgáltak: kutatásuk azt mutatta, hogy a diákok motivációja és bevonódottsága nő, de az előrehaladásra már nem volt hatással a gamifikáció. Hanus and Fox (2015) pedig két azonos témájú kurzus hallgatóit vizsgálta, egy 16 hetes szemeszter során: az egyik kurzus gamifikált volt, míg a másik hagyományos. A kutatók alacsonyabb motivációt mértek a gamifikált hallgatók esetében, mint a hagyományos módon tanuló hallgatóknál.

Az eredmények értékelését a fogalomhasználat sokfélesége is nehezíti. Borges és munkatársai (2014) a gamifikációval foglalkozó tanulmányok áttekintése során azt tapasztalták, hogy a motiváció fogalma gyakran megjelenik, azonban az egyes tanulmányok nagyon sokféle tartalmat jelenítettek meg ezzel a címszóval. Ide tartozott például

- a tanulók különféle készségeinek fejlesztése,

- valamilyen kihívás teljesítése a tanulási tartalom megerôsítése érdekében,

- a tanuló elköteleződésének növelése a tartalom könnyebben érthetővé tétele által,

- a tudáselsajátítás növelése,

- viselkedésbeli változás elérése,

- társas tanulás, szocializáció.

Az elmúlt néhány év összegző, áttekintő vizsgálatai a gamifikációval foglalkozó kutatásokat, tanulmányokat sokféle szempontból értékelték. Mivel a tanulmányok kiválasztásánál a sokféle szempont mellett a megjelenés 
helye és nyelve (angol) is szerepel, ezért országokra bontva viszonylag kevés szerző mutatja be a forrásokat. Caponetto és munkatársai (2014) erre is kitértek: az általuk vizsgált 120 tanulmány 28 százaléka az USA-ban született. Kiemelkedő, hogy Románia 7 százalékkal került a mintába, míg például Lengyelország 3 százalékkal, Ausztrália és Németország is 3-3 százalékkal képviseltette magát. Magyarországot nem említi a tanulmány, bár elképzelhető, hogy az „egyéb” kategóriába hazai szerzők vizsgálta is bekerült.

Az oktatási szintre, alkalmazási területre minden áttekintő tanulmány kitér. Általános tapasztalat, hogy a kutatások többsége a felsőoktatásban és a felnőttképzésben születik (Caponetto és tsai., 2014, Dicheva és tsai., 2015, Majuri és tsai., 2018). Az 1. táblázatban Borges és munkatársai (2014) adatait mutatjuk be, jellemzően más szerzőknél is ilyen arányok jelennek meg.

1. táblázat: A gamifikációval foglalkozó tanulmányok, oktatási szint szerint. Forrás: Borges és tsai, 2014

\begin{tabular}{|l|c|c|}
\hline Oktatási szint & $\mathbf{N}$ & $\mathbf{\%}$ \\
\hline Felsőoktatás & 12 & 46,15 \\
\hline Többféle oktatási szint & 6 & 23,08 \\
\hline Tréning & 3 & 11,54 \\
\hline Nyelvoktatás & 2 & 7,69 \\
\hline Általános iskolai oktatás & 2 & 7,69 \\
\hline Élethosszig tartó tanulás & 1 & 3,85 \\
\hline
\end{tabular}

A Caponetto és munkatársai (2014) által vizsgált 120 tanulmány eredményei közül érdemes kiemelni, mely kifejezéseket találták a leggyakoribbnak a vizsgált szövegekben. A két leggyakrabban említett szó a „növelni” (increase) és a „fejleszteni” (improve), amelyek a gamifikáció hozzáadott pedagógiai értékére utalnak. További két gyakori kifejezés a „társas” (social) és a „tervezés/kivitel” (design). Ezek közül az első a tanulás társas kontextusa kapcsán jelenik meg, és a gamifikáció szociális készségeket is fejleszteni képes mivoltára hívja fel a figyelmet. A második pedig arra vonatkozik, hogy a tanulási beavatkozásokat és tevékenységeket különös figyelemmel kell végiggondolni és megtervezni a gamifikáció során.

A szociális fejlesztési lehetőségek kapcsán Majuri és munkatársai (2018) viszont épp arra hívják fel a figyelmet, hogy ezek mérése gyakran elmarad: a hangsúly a mérhető (tanulmányi) előrehaladáson van. Az általuk vizsgált 128 empirikus tanulmányban a leggyakoribb téma a haladás/fejlődés, ezen belül a pontok megszerzése, a feladatok, küldetések, valamint a célok pontos megfogalmazása. A szintezéssel már csupán 35 tanulmány foglalkozik, és csak feleennyi (18 darab) a visszacsatolással, visszajelzéssel. A társas készségek kapcsán a csapatmunka, együttműködés témája kerül elő leggyakrabban (31 esetben), és mindössze 14 tanulmány foglalkozik a társas kapcsolatokkal, hálózatok építésével. Még ennél is ritkábbnak bizonyult a társas/szociális kapcsolódások megjelenése, amikor a tanulmányokon belül a pszichológiai és/vagy a viselkedésben bekövetkező változások említését vizsgálták a kutatók: mindössze tíz tanulmány tért ki a társas interakciókra. Érdemes még kiemelnünk az empirikus 
kutatások eredményét: 71,43 százalékuk jelezte, hogy a gamifikációnak pozitív hatása van a tanulás során, a fennmaradó közel harminc százalék viszont semlegesnek mondható: vagy nem mértek szignifikáns eltérést, vagy pozitív és a negatív hatások egyaránt megjelentek az eredmények sorában.

Hasonló arányokat tapasztaltak Dicheva és munkatársai (2015): az általuk áttekintett 34 tanulmányból 14 mutatott vegyes vagy negatív eredményt, és fogalmazott meg különféle ajánlásokat a hatékonyság érdekében. Ezek általában a motivációs elemek hiányára mutattak rá, vagy a tervezési hibákra, például a feladatok/küldetések kialakítása során. A társas vonatkozásokkal az általuk vizsgált tanulmányok fele foglalkozott, ezek - hasonlóan a fent idézett vizsgálat eredményéhez alapvetően a versengés és a csapatmunka témakörét említették valamilyen összefüggésben.

\section{Összegzés}

A gamifikáció és az oktatás kapcsolata dinamikus fejlődésnek indult az utóbbi években. Úgy tűnik, hogy a diákok elkötelezettsége, motiváltsága egyértelmúen növelhető a játékelemek bevonásával. Ugyanakkor a kutatások többsége a felsőoktatással és/vagy a felnőttképzéssel foglalkozik, így a közoktatásban történő alkalmazásról viszonylag kevés eredmény áll rendelkezésünkre.

A gamifikáció lehet strukturális vagy tartalmi. Utóbbi kapcsán számos kérdés merül fel, például, hogy mennyiben felel meg a gamifikáció sajátosságainak egy-egy alkalom- szerűen megjelenő játékos feladat, vagy a játékjellegű dizájnt nélkülöző digitalizált tesztek használata. E terület kutatását nehezíti a nem mindig tiszta fogalomhasználat: az edutainment programokat vagy a Game-Based Learninget is gyakran nevezik gamifikációnak.

A strukturális gamifikáció fogalmai körülhatároltabbnak tűnnek. Az empirikus tanulmányok aránya egyelőre nem nagy, és elmondható, hogy többségük a struktúra kialakításával, így például a pontrendszerrel, a szintekkel, a jutalmakkal foglalkozik. Viszonylag keveset tudunk a tanulási folyamat olyan elemeiről, mint a memória ideális terhelése, vagy akár a visszacsatolás leghatékonyabb módozatai. Az, hogy az empirikus tanulmányok egyharmada vegyes vagy negatív hatásokat mér, arra hívja fel a figyelmünket, hogy a tervezés és az alkalmazás során körültekintően kell eljárni, illetve, hogy szükség van olyan kutatásokra, amelyek a gamifikáció hatékonyságát, kontextusát, társas hatásait vizsgálják.

\section{Irodalom}

Balogh Andrea (2017). Digitális játékok az oktatásban. Anyanyelv-pedagógia, 10(1), 5362.

Borges, Simone De Sousa, Durelli, Vinicius H. S., Reis, Helena Macedo and Isotani, Seiji (2014). A Systematic Mapping on Gamification Applied to Education. SAC. Doi: $\underline{10.1145 / 2554850.2554956}$

Bradley E. Wiggins (2016). An Overview and Study on the Use of Games, Simulations, 
and Gamification in Higher Education. International Journal of Game-Based Learning, 6(1), 18-29.

Caponetto, Ilaria, Earp, Jeffrey and Ott, Michela (2014). Gamification and Education: A Literature Review. ECGBL, Berlin, 2014. October 9-10

Clark, Ruth, Nguyen, Frank and Sweller, John (2006). Efficiency in learning: Evidencebased guidelines to manage cognitive load. San Francisco: Pfeiffer

Deterding, Sebastian (2014). The Ambiguity of Games: Histories and Discourses of a Gameful World. In: Walz, Steffen P. and Sebastian Deterding (eds.): The Gameful World. Approaches, Issues, Applications. Cambridge, MA: MIT Press. 23-64.

Dicheva, Darina, Dichev, Christo, Agre, Gennady and Angelova, Galia (2015). Gamification in Education: A Systematic Mapping Study. Educational Technology \& Society, 18(3), 1-14.

Domínguez, Adrián, Saenz-de-Navarrete, Joseba, de-Marcos, Luis, Fernández-Sanz, Luis, Pagés, Carmen and MartínezHerráiz, José-Javier (2013). Gamifying learning experiences: Practical implications and outcomes. Computers \& Education, 63(1), 380-392.

Fromann Richárd és Damsa Andrei (2016). A gamifikáció (játékosítás) motivációs eszköztára az oktatásban. Új Pedagógiai Szemle, 3-4, 76-81.

Hanus, Michael D. and Fox, Jesse. (2015). Assessing the effects of gamification in the classroom: A longitudinal study on intrinsic motivation, social comparison, satisfaction, effort, and academic performance. Computers \& Education, 80, 152-161.

Kenéz András (2016). A játékosítás (gamification) a felsőoktatásban. In: Fehér András, Kiss Virág Ágnes, Soós Mihály és Szakály Zoltán (szerk.) Hitelesség és értékorientáció a marketingben. Debreceni Egyetem Gazdaságtudományi Kar, Debrecen. 276-288.

Kovácsné Pusztai Kinga (2018). Játékosítás (gamification) az oktatásban. In: Szlávi Péter és Zsakó László (szerk.) InfoDidact' 2018 Elöadáskötet. Webdidaktika Alapítvány, Budapest. 93-102.

Majuri, Jenni, Koivisto, Jonna and Hamari, Juho (2018). Gamification of education and learning: A review of empirical literature. GamiFIN Conference 2018, Pori, Finland, May 21-23, 2018

Perrotta, Carlo, Featherstone, Gill, Aston, Helen and Houghton, Emily (2013). Game-based learning: Latest evidence and Future Directions. Slough: National Foundation for Educational Research Turan, Zeynep, Avinc, Zeynep, Kara, Kadir and Yuksel Goktas (2016). Gamification and Education: Achievements, Cognitive Loads, and Views of Students. International Journal of Emerging Technologies in Learning, 11(7), 64-69 